\title{
A REMARKABLE NEW GENUS AND SPECIES OF TWO- WINGED FLIES RELATED TO THE OESTRIDAE
}

\author{
By Charles H. T. Townsend \\ Itaquaquecetuba, Sao Paulo, Brazil
}

Dr. J. M. Aldrich has asked me to name and describe an extremely interesting fly which he sent me for examination and which I believe to be the most important oestromuscoid discovery of the twentieth century from the taxonomic point of view.

After long deliberation, I arrived some years ago at the conclusion that the oestriform tachinids or Tachino-Oestridae of Villeneuve (Aulacephalini, Ormiini, Trixodini, Trixini, Palpostomatini, Paratrixini, Glaurocarini, and Myiotrixini) all belong in the same family with the Oestrini, despite the apparent gap between the last-named tribe and all the others. There was no known form that would fit in the Oestrini better than in any of the other tribes and yet show some of the widely different characters of the latter, such as well-developed macrochaetae, developed haustellum, and ventral membrane concealed.

The present form closes this gap between the Oestrini and the other tribes of Oestridae above named. Its venation and head conformation are both strikingly oestrine and preclude its reference to any of the other tribes, yet the ventral membrane is concealed, the proboscis is considerably developed, and the bristles are well developed.

\section{OLIGOOESTRUS, new genus}

Genotype.-Oligooestrus oestroideus, new species.

Male.-Form moderately narrowed. Head (fig. 1) subelliptic in front view, roundly bulging below, about one-fourth wider than high, its profile subsemicircular; frontal profile flat, well sloped, twice as long as facial profile to vibrissae; facio-oral profile arcuate; clypeus depressed, cuplike, a little longer than wide, no facial carina; epistoma nearly twice as long as clypeus, arcuately receding, somewhat over half as wide as clypeus, a little widened above and more below; facialia bare, half as wide as clypeus, obliquely flattened; vibrissae decussate, longer than the bristles below them; vibrissal

No. 2942.-Proceedings U. S. National Museum, Vol. 82, ARt. I 
angles set high above lower border of head; 8 or 9 weaker and shorter bristles below vibrissae, 1 pair decussate; vibrissal area proper is glabrous, rather elongate, and narrowed, with few hairs outside peristomal row to mark its separation from cheek-grooves; vibrissal axis considerably shorter than antennal, latter about threefourths head height; oral cavity shallow, rostrum recessive, haustellum as long as antennae, labella knoblike and nearly as long as haustellum, palpi only microstubs; antennae on eye middle, approximated at base, very small and short, first joint flush, second very short with 1 long bristle; third joint microseedlike, as long as second, basal half inserted in latter; arista little longer than antennae, scarcely longer than the bristle of second antennal joint, arising

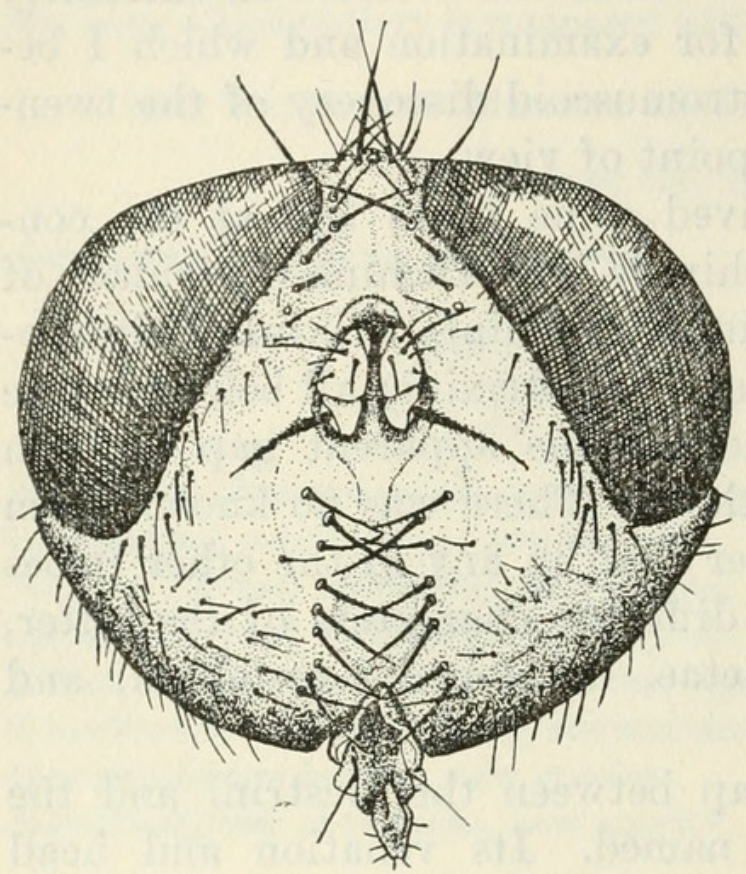

FigURE 1.-Oligooestrus oestroideus, new gemus and species: Head of male from in front

from middle of third antennal joint, thickened only at base, short-pubescent, bas a l joints short; eyes bare, faintly oblique on lower part, reaching vibrissal level, facets equal; vertex onesixth head width; front narrowed to one-seventh head width on middle, widening rapidly to onehalf head width at base antennae; face widening rapidly from front, two-thirds head width at level of lower border of eyes; frontals stopping at base antennae, weak, anterior one stronger, 6 or 7 in all, not hugging frontalia; inner verticals straight, outer absent; no fronto-orbitals; frontalia considerably narrowed posteriorly, nearly three times as wide as one parafrontal, smooth; ocellar triangle reaching two-fifths of the way to lunula, triangular, filling vertex, longer than wide; only 2 ocelli, the front one absent; ocellars proclinate-erect, parallel, as long as anterior frontals; postocellars weak, erect; postverticals shorter than postocellars; parafrontalia setose, faintly sloped anteriorly; parafacialia equibroad, oblique to clypeal plane, as wide as clypeus plus both facialia, outer one-third to one-half with erect bristles, no facio-orbitals; cheek three-fourths the eye length; cheek grooves rather large, facing forward, with 3 long prongs; no genoorbitals; occipital area invading most of cheeks, its vestiture fine like that of occiput.

Infrascutellum well developed; lateral postscutellar plates, squamopleura, prosternum, and propleura bare; prosternum moderately 
wide, its membrane bare and not inflated; prescutum much shorter than postscutum; postalar wall, tympanic ridge, and pit bare; greater ampulla very small, seedlike, somewhat raised, convex, bare; 1 preacrostichal, the middle one; 1 postacrostichal, 2 presuturals, 3 postsuturals; 1 preintraalar, the front one; 2 postintraalars, 1 presupraalar, 1 postsupraalar, 3 humerals, 1 intrahumeral, no posthumeral, 2 postalars, no intrapostalar, 2 or 3 mesopleurals and many hairs below, one weak upper mesopleural, 1 mesopleural-spiracular, 1 propleural; 1 sternopleural, the front one; pteropleura with a few bristles in a bunch, 5 hypopleurals; 2 lateral scutellars, middle one lacking, hind one strong, no apicals.

Wings (fig. 2) little over twice as long as broad, wide on middle and narrowing at both base and tip, veins crowded into less than costal half; alulae rather large, erect, half as wide as long; costal spine quite strong, as long as small cross vein; remigium bare, its

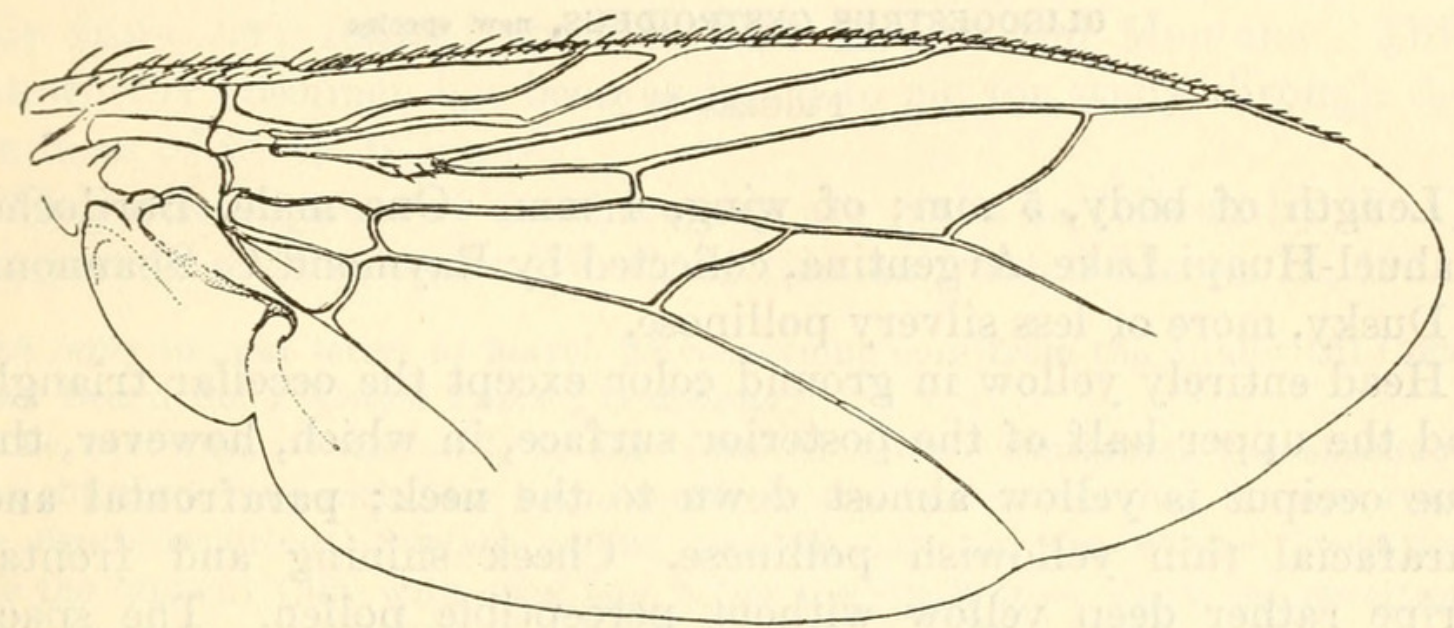

Figure 2.-Oligooestrus oestroideus, new genus and species: Wing

inferior proximal process also bare; apical cell long-petiolate, the petiole as long as hind cross vein, in line with third vein and reaching margin nearly twice the length of hind cross vein before wing tip; first vein bare and terminating close beyond auxiliary vein; third vein with 2 microbristles at base; small cross vein short, straight, nearly on outer two-thirds of discal cell, opposite tip of hind cross vein, halfway between tips of auxiliary and first veins; apical cross vein sinuate, long stump and wrinkle at cubitulus; latter angular, very obtuse, three-fifths wing width from hind margin; hind cross vein sinuate, midway between small cross vein and cubitulus, nearly parallel with apical cross vein; fifth vein bare, its last section much longer than preceding section; squamae bare, nearly as wide as long, rounded on both outer and inner hind corners, somewhat projecting outside, squamae nearly one-fifth their area.

Legs not elongate, not stout, rather finely bristled, tarsi moderately long and all joints well bristled, front coxae little longer than hind 
coxae; hind tibiae with three longer bristles and some short hairs, all the metatarsi much shorter than the following joints taken together; claws elongate, very slender and delicate, thickened on base.

Abdomen very short-ovate, rounded behind, somewhat flattened, little wider than thorax and same length, a little longer than wide; basal segment short, first sternite much wider than second; second to fourth sternites exposed, second longer than wide, all narrow, no membrane visible except narrowly at base of second sternite; no marginals on first segment, only a single pair of very short appressed median marginals on second segment, marginal row on third segment but only one median marginal pair erect, erect marginal row on fourth segment; first hypopygial tergite with marginal row and inferior aspect, second with same aspect but no marginal row; hypopygium ventral and rather large, lobes of fifth sternite moderately large and sternite set forward to near midventer.

\section{OLIGOOESTRUS OESTROIDEUS, new species}

Figures 1, 2

Length of body, $5 \mathrm{~mm}$; of wing, $4 \mathrm{~mm}$. One male, Bariloche, Nahuel-Huapi Lake, Argentina, collected by Raymond C. Shannon. ${ }^{1}$

Dusky, more or less silvery pollinose.

Head entirely yellow in ground color except the occellar triangle and the upper half of the posterior surface, in which, however, the true occiput is yellow almost down to the neck; parafrontal and parafacial thin yellowish pollinose. Cheek shining and frontal stripe rather deep yellow without perceptible pollen. The space inside the lunule below is shining with a dark translucent appearance. Thorax, abdomen, and legs black; tip of scutellum distinctly yellow. Mesonotum with rather dense tessellated brownish-yellow pollen, the stripes changing greatly with the angle of view. Dorsum of abdomen rather evenly and thinly covered with gray pollen, somewhat denser on fourth segment. Wings gray; squamae white including rim.

Type.-Male, U.S.N.M. No. 43802.

\footnotetext{
${ }^{1} \mathrm{Mr}$. Shannon collected three specimens of this fly on the same date; only one was sent to Doctor Townsend, which becomes the type; one is retained by Mr. Shannon; the third is to be deposited in the British Museum. All are males.

The drawings for the two figures herein were made by Mrs. Eleanor Carlin, through the kindness of the Bureau of Entomology.-J. M. ALDRICH.
} 


\section{$2 \mathrm{BHL}$ Biodiversity Heritage Library}

Townsend, C. H. T. 1932. "A remarkable new genus and species of two-winged flies related to the Oestridae." Proceedings of the United States National Museum 82(2942), 1-4. https://doi.org/10.5479/si.00963801.82-2942.1.

View This Item Online: https://www.biodiversitylibrary.org/item/32567

DOI: https://doi.org/10.5479/si.00963801.82-2942.1

Permalink: https://www.biodiversitylibrary.org/partpdf/8980

\section{Holding Institution}

Smithsonian Libraries

\section{Sponsored by}

Smithsonian

\section{Copyright \& Reuse}

Copyright Status: NOT_IN_COPYRIGHT

Rights: https://www.biodiversitylibrary.org/permissions/

This document was created from content at the Biodiversity Heritage Library, the world's largest open access digital library for biodiversity literature and archives. Visit BHL at https://www.biodiversitylibrary.org. 